\title{
31. Batı Trakya'da asimilasyon, unutturma ve (toponimi özelinde) isim değişikliği
}

\section{Selda ADİLOĞLU1}

\begin{abstract}
APA: Adiloğlu, S. (2021). Batı Trakya'da asimilasyon, unutturma ve (toponimi özelinde) isim değişikliği. RumeliDE Dil ve Edebiyat Araștırmaları Dergisi, (22), 510-526. DOI: 10.29000/rumelide.886164.
\end{abstract}

\section{$\ddot{O} \mathbf{z}$}

Söylem düzeyinde Yunan hükümeti için Türkler, kökenlerinde "Yunanlı"lı bulunan birer bölge sakini durumundadır. Uygulamada ise ülkeden gönderilmeleri gereken yabancılar veya Yunanlılaştırılmaları elzem azınlıklardır. Bu algıdan hareketle de yönetim, bir yanda bölge Türklerini göçe itmekte diğer tarafta ise kimlik, kültür ve hafıza temelinde Yunanlılaşmalarına dönük bir takım uğraşlar sergilemektedirler. Göç, Yunan hükümetinin Türklere yönelik ilk uygulamalarından birisidir. Yaşanan göçlerle Batı Trakya'daki Türk nüfusu azalmıştır. Bugün tüm Batı Trakya'da 350.00o dolayında kişi yaşarken bu nüfus içinde Türklerin sayısı 150.00o civarındadır. Göçe ilaveten ise bölge içinde ara ara değişik uygulamalara rastlanmaktadır. Türklerin yaşam olanaklarını kısıtlamak, kamulaştırma yoluyla Türk köylerini ortadan kaldırmak ve ismen haritadan silmek, "Türk" ibaresini tabelalardan sökmek ve Türkçe yer isimlerini değiştirmek, başlıca uygulamalardır. Çalışma, Yunanlılaştırma söylemi üzerinden bölgede devam eden asimilasyon hususunun uygulama boyutuna eğilmektedir. Dolayısıyla bu kapsamda, asimilasyona maruz bırakılmış bireyler ve bu bireylerdeki tezahüründen ziyade asimilasyona vesile olacağı düşünülen uygulamalara bakılmaktadır. Gaye, bölgedeki asimilasyonu, unutturma pratiği ve buna vesile olabileceği düşünülen “toponimi değişikliği” mevzusu özelinde değerlendirmektir. Burada, toponiminin veya yer isimlerinin geçmişi temsil kabiliyetinin olduğu ve bu yönüyle yönetimler için müdahalesi kaçınılmaz bir niteliğe büründüğü görülmektedir. Batı Trakya özelindeki duruma bakıldığında, Yunanistan’ın, Osmanlı'dan sadece bir kara parçası almadığı, farklı etnik gruplarla birlikte yoğun bir Türk nüfusu, Türk kültür ve tarihini de devraldı̆̆ı anlaşılır. Çalışmada, Türk kültür ve tarihiyle şekillenmiş bir geçmişin her anlamda dönüşümünün Yunan hükümetince kaçınılmaz hale geldiği ve hızlıca Türkçe olan yer adlarını, Yunancaya dönüştürdüğü fark edilir.

Anahtar kelimeler: Batı Trakya Türkleri, Yunanlılaşma, unutturma, toponimi değişikliği

\section{Assimilation, forced forgetting (effacing cultural memory) and name change (special for toponymy) in Western Thrace}

\begin{abstract}
Regarding the official discourse, for the Greek government, the Turks are simply the residents of the region with "Greek" origin. In practice, they are the foreigners who need to be sent away from the country or essential minorities to be Graecized. Driven by this view, on the one hand, the Greek government forces the Turks of the region to emigrate; on the other hand, it makes efforts towards their Graecization on the basis of identity, culture and memory. Emigration is one of the earliest policies implemented by the Greek government regarding Turks. The Turkish population in
\end{abstract}

Dr. Öğr. Üyesi, Bursa Teknik Üniversitesi, İTBF, Sosyoloji Bölümü (Bursa, Türkiye), selda.adiloglu@btu.edu.tr, ORCID ID: oooo-0002-9725-436X [Araştırma makalesi, Makale kayıt tarihi: 24.11.2020-kabul tarihi: 20.03.2021; DOI: 10.29000/rumelide.886164].

RumeliDE Dil ve Edebiyat Araşttrmaları Dergisi Osmanağa Mahallesi, Mürver Çiçeği Sokak, No:14/8 Kadıköy - İSTANBUL / TÜRKIYE 34714 e-posta: editor@rumelide.com tel: +90 $5057958124,+902167730616$
Address

RumeliDE Journal of Language and Literature Studies Osmanağa Mahallesi, Mürver Çiçeği Sokak, No:14/8

Kadıköy - ISTANBUL / TURKEY 34714

e-mail: editor@rumelide.com,

phone: +90 505 7958124, +90 2167730616 
Western Thrace has decreased with the migrations. Today, around 350,00o people live in Western Thrace, while the number of Turks in this population is around 150,000. In addition to emigration, there are some other policies put into effect in the region in various times. Restricting the alternatives available for Turks, eliminating Turkish villages through expropriation and removing them from the Greek map by name, removing the phrase "Turk" from the signs and changing the Turkish place names are the some of the most common practices. The study focuses on the implementation dimension of the ongoing assimilation issue in the region through the Graecization discourse. Therefore, in this context, rather than the manifestation of assimilation at the individual level and individuals who have been subjected to assimilation, the research focus was placed on the practices that are thought to be conducive to assimilation. The aim is to evaluate the assimilation in the region in terms of the practice of forced forgetting and the "toponymy change", which is thought to be the cause. Here, it is seen that toponymy, or name of a place, has the ability to represent the past, and in this respect, the intervention of the administrations is inevitable. Considering the specific situation in Western Thrace, it is obvious that Greece did not only take a piece of land from the Ottoman Empire, but also a dense Turkish population, culture and history along with different ethnic groups. In the study, it is evident that the transformation of a past shaped by Turkish culture and history in every sense has become inevitable for the Greek government, which quickly changed the place names from Turkish into Greek.

Keywords: Turks in Western Thrace, Greekness, (Forcibly) forgetting, toponymy change

\section{Giriş}

Anadolu dışında yaşayan Türkler için Makas (1993), kimisinin onları Çinlileştirmeye, kimisinin Ruslaştırmaya, Araplaştırmaya, bir kısmınınsa Bulgar, Yunan veya başka bir millete dönüştürmeye uğraştıklarını, Türklüklerinden uzaklaştırmaya çalıştıklarını aktarır. Her türlü baskıya rağmen ise bu insanların milliyetlerini yitirmemeleri üzerine ülkelerin, toponimide bir takım değişikliklere gitme yolları seçtiklerini ilave eder. Yapılan genellemenin, Yunanistan’a bağlı bulunan Batı Trakya Türkleri özelinde geçerliliğinin olduğu belirtilebilir. Bölge sakinlerini asimile etmeye dönük yapılan uygulamalar, göçte olduğu gibi ortak amaca hizmet etmiş ve hemen hemen aynı tarihlerde (1920'li yıllar) bölge genelinde görünür hale gelmeye başlanmıştır. Yunan hükümeti, bölgedeki Türk varlığını ortadan kaldırmaya dönük ya ülkeden uzaklaştırma ya da Helenleştirme (çalışmada Yunanlılaştırma anlamında kullanılmaktadır) yolundan birini uygulamıştır. Bu iki yoldan biri olan "göç", Batı Trakya Türkleri denince akla gelen olguların başında gelir ve bu nedenledir ki, Batı Trakya meseleleriyle ilgili kaleme alınmış çalışmaların büyükçe bir kısmı göçü farklı boyutlarıyla irdeler. Bu metinde de görüleceği üzere Batı Trakya'dan göçürülen Türkler, parçası olmadıkları süreçlerin başlıca mağdurları durumundadır. Diğer yanda göç etmeye direnebilenlerin bulunduğu noktadan bakıldığında Batı Trakya Türklerinin farklı nitelik ve zaman dilimlerinde çeşitli uygulamalara maruz kaldıkları anlaşılır. Bunların arasında, Makas'ın iddiasını destekler şekilde, toponimik düzeyde yapılan değişiklikler yer alır. Zira yine Makas'ın Anadolu dışındaki Türkleri kapsar şekilde dediği gibi baskılara rağmen milliyetlerini yitirmeyen bu insanlara Yunan yönetimi bir de toponimide yaptığ bir takım değişikliklerle yaklaşmaya ve onları, Türklüklerinden uzaklaştırmaya veya daha teknik bir terimle asimile etmeye odaklanır. Bu çalışmanın, akademik bir boyuta taşınmasındaki başlıca motivasyon da Yunan yönetiminin toponomi düzeyinde yaptığı değiş̧iklikler ve bu değişikliklerin akademik yazında yer almamış olmasıdır. Kamulaştırma veya Türk isminin yasaklanması, gündelik hayatta ve alan yazında tepki ve dikkat çekmiş olmasına karşın yer adı değişikliklerine önem verilmemiştir. Bu da sürecin sessizce ve hızlıca gerçekleşmesine ve sonuçlanmasına yol açmıştır. Değirmendereli (1993:5),

RumeliDE Dil ve Edebiyat Araştırmaları Dergisi Osmanağa Mahallesi, Mürver Çiçeği Sokak, No:14/8 Kadıköy - İSTANBUL / TÜRKIYE 34714 e-posta: editor@rumelide.com tel: +90 505 7958124, +90 2167730616
Address

RumeliDE Journal of Language and Literature Studies

Osmanağa Mahallesi, Mürver Çiçeği Sokak, No:14/8

Kadıköy - ISTANBUL / TURKEY 34714

e-mail: editor@rumelide.com,

phone: +90 505 7958124, +90 2167730616 
Assimilation, forced forgetting (effacing cultural memory) and name change (special for toponymy) in Western Thrace / S. Adiloğlu (pp. 510-526)

bölgede Türklüğün silinmez izleri olarak nitelendirdiği yer ve yerleşim adlarıyla ilgili herhangi bir incelemenin yapılmadı ̆̆ını belirtmektedir. Yazarın iddiası, konuyla ilgili yapılan yüzeysel bir literatür taramasında dahi gün yüzüne çıkar. Zira bölgedeki Türkçe yer adlarının değişim sürecini, doğasını ve sayısını ele alan kapsayıcı bir akademik çalışma yoktur. Bu bağlamda çalışmanın amacı, asimilasyon için başvurulan kamulaştırma, Türk isminin yasaklanması, azınlı statüsü ve/veya vatandaşlıktan çıkartma gibi görünür ve tartışılan uygulamaların yanında sessizce gerçekleşen yer ismi değişikliklerini alan yazına duyurmaktır. Bu kapsamda çalışma, söz konusu uygulamanın, Yunan yönetimi için bölgedeki Türklüğü "unutturma”da önemli bir araç vazifesi gördüğünü, unutturmanın gerekçesinde ise "yapay” bir Yunan coğrafyası yaratmanın yer aldığını ortaya koymaya odaklanmaktadır.

Burada bölgeye ve bölge Türklerine geçmeden önce, neden "toponimik" düzeyde bir müdahaleye ihtiyaç duyulduğu sorusuna cevap aranabilir. Bu müdahale tipinde esas olan, yer adlarının değiştirilmesidir. Yunan hükümeti, Osmanlı'dan salt yönetsel bir yapıyı değil, demografik ve toponimik bir düzeni de devralmıştır. Bu düzenin içinde Yunan hükümetini huzursuz eden başlıca hususlarsa "Türkler"le birlikte konuştukları dilleri "Türkçe” olmuştur. Bu huzursuzluğu giderici yönde yönetimin bir takım uygulamalara giriştiği görülür. Bunlardan ilki göçtür, bölge Türklerinin Batı Trakya'dan daimi olarak göçleridir. Bir diğeri ise göç etmeyenlerin Yunanlılaşmaları, Helenleşmeleri veya asimilasyonlarıdır.

"Yunanlılaşma", Jansen'in açıklamasında (2013), Amerikanlılaştırma ve/veya Fransızlaşma örnekleriyle benzeşir ve bunu mümkün kılanın asimilasyon olduğu görülür. Yazara göre, bir şeyin başka bir şeye benzemesi eylemi, fizyolojide 1495 yılından beri vardır, insanlar özelinde kullanımı ise 1840'lı yıllarla gelişir ve böylece insanların da tıpkı şeyler gibi asimile edileceği fikri ortaya çıkmış olur. Bu da kavramın politik-sosyoloji söylemi içinde işlevselleşmesini beraberinde getirmiş olur. Çalışma bağlamında düşünüldüğünde insanların, "başka" insanlara benzemesi/benzetilmesi eylemi, Türklerin Yunanlılaştırılması örneğinde görünür hale gelir. Bunun da gerçekleşebilmesinde "unutma" eyleminin etkili olduğu anlaşılır. Unutma bağlamında yazar (Connerton, 2014:56), Erns Renan'dan alıntılayarak tarihsel bir olayı çalışmasına taşır. Buradaki vurgu uluslaşma (veya daha genel bir ifade ile tek bir etnik bütünlüğe varmak için asimile olmak) için unutmanın gerekliliğidir. Olay bazında düşünüldüğünde bu aktarıma (Connerton, 2014:56) göre, yazar Renan, Fransa'nın uluslaşma sürecinde unutmayı bir taktik olarak görüp kullanmasını işlemektedir:

Unutkanlı, hatta ileri gidecek olursam, tarihsel yanılgı bir ulusun ortaya çıkabilmesi için elzemdir. Köylüler, Fransız vatandaşlarına dönüştürülürken, Fransız vatandaşı olduklarını öğrenebilmek için köylü olduklarımı kısmen unutmaları gerekiyordu.

Görüleceği üzere Fransa, uzun zaman önce, uluslaşabilmek için “unutma”yı bir taktik, bir araç olarak kullanmıştır. Bu sayede köylü Fransızlar, bugünün Fransızları olabilmeleri için köylülüklerini unutmuş, köylülüklerini unutabildikleri düzeyde de birer Fransız vatandaşı olabilmişlerdir. Eldeki örnekler uluslaşabilme ve pek tabi ulus-devlet olabilmede ülkenin/ülkelerin, devr aldığı topluluk kadar üzerinde yer aldığı toprağı da uluslaştırma yoluna gittiğini gösterir. Bu kaynaktaki örneklerden birinde (Hacısalihoğlu ve Özcan, 2013: 1328), Romalıların Kudüs'ü Yahudilerden bütünüyle ve sonsuza dek arındırmak için Yahudilik için kutsal çağrışımı olan Yerüşelayim olan yer ismini Aelia Capitolina olarak değiştirdiği aktarılır.

Yunan hükümetinin Batı Trakya Türklerine yönelik izlediği adımlar göz önünde bulundurulduğunda bir Fransa örneğinin ya da Kudüs örneğinin ylllar sonra tekerrür ettiği görülür. Yunan hükümeti de bölge Türklerini Yunanlılaştırabilmek (veya Helenleştirmek) için onların Türklüklerini unutturmaya

Adres Address

RumeliDE Dil ve Edebiyat Araştırmaları Dergisi $\quad$ RumeliDE Journal of Language and Literature Studies Osmanağa Mahallesi, Mürver Çiçeği Sokak, No:14/8 Osmanağa Mahallesi, Mürver Çiçeği Sokak, No:14/8 Kadıköy - ISTANBUL / TÜRKIYE 34714 Kadıköy - ISTANBUL / TURKEY 34714 e-posta: editor@rumelide.com e-mail: editor@rumelide.com tel: +90 505 7958124, +90 2167730616 phone: +90 505 7958124, +90 2167730616 
girişmiştir. Bu girişime, Türkçeyi ve "Türk" terimini hatırlatan her ne varsa ortadan kaldırmakla başlamıştır. Mesela, kimliğin bir göstergesi olarak kabul gören yer adlarını Türkçeden Yunancaya çevirmiş, Türkçe versiyonunun kullanımını yasaklamıştır. Yer adları veya teknik versiyonuyla toponimi, asimilasyonun görünmez tekniklerinden birisidir. Zira mekâna sinmiş veya mekânla şekillenmiş hafıza, mekânın ismen değişimiyle hafızayı da dönüştürecek potansiyeli açı̆̆a çıkarabilmektedir. Bu nedenledir ki, Yunan hükümeti, yönetimi ele geçirir geçirmez toponimik düzeyde dönüşümlere kalkışmıştır. Ülkenin gerçekleştirdiği toponimi değişiklikleriyle ilgili olarak Bakirtzis ve arkadaşları (2014), yapılanların, "oldukça politik bir eylem” olduğu değerlendirmesinde bulunurlar. Eylemin politik olmasından kasıt, eylemin içeriğidir. Zira Assman’ın (1997:79) da iddia ettiği gibi iktidarlar, kendileri için geriye yönelik meşruluk ve ileriye yönelik ebedilik arayışında olup sadece geçmişi değil geleceği de gasp edebilmelerine odaklanırlar. Bunun için ideal yollardan biri, hafızayı dönüştürebilmekten geçer. Connerton (2014:14), hafıza becerisini geliştirmek gerektiğini belirtir ve bunun için de insanların bir yere ihtiyaç duyduklarını, hatırlamayı istedikleri şeylerin görüntülerini zihinlerinde canlandırabilmek için de onları, belirledikleri yerlere depolamaları gerektiğini aktarır. Depolama ve depolanacak yer mevzusu, burada doğrudan yer adlarını akla getirmektedir. Batı Trakya konusuna dönmeden önce burada yine Assmann'ın iddia veya açıklamalarına yer verilebilir. Yazar (Assmann,1997), kendilerini grup olarak sağlamlaştırmayı isteyen her bir topluluğun sadece içsel iletişim biçimlerinin sahnesi olarak değil aynı zamanda kimliklerinin sembolü ve hatıralarının dayanak noktası olarak da mekânları yaratmak ve onları garanti altına almak istediklerini belirtir. Dolayısıyla çalışma kapsamında düşünüldüğünde Yunan hükümetinin topyekûn şekilde bir gelenek, yönetim ve/veya bir ulusal birlik kurgulayabilmesi için ister istemez ona ait ve onu hatırlatacak bir mekânı yaratmasına ve onu sürdürebilmesine ihtiyacı vardır. Burada "mekân yaratma" ifadesi kapsayıcı ve anlamlıdır. Zira Yunanistan yönetsel düzeyde parçası olan Batı Trakya bölgesini kendi ihtiyaç ve emellerine bağlı olarak kurgulamak ve “inşa etmek”le uğraşmaktadır.

\section{Batı Trakya: Yunan hükümetinin odağında bir bölge}

Bugün "Batı Trakya", tüm bir Trakya'nın birkaç antlaşma (Neuilly Antlaşması ve Lozan Antlaşması gibi) sonucu üçe bölünmüş parçalarından birisidir. Bu bölünmeye göre, Bulgaristan'a Rodop Dağlarının kuzeyinde kalan bölümü, Türkiye’ye Meriç (Evros) Nehrinin doğusundaki bölümü ve Yunanistan'a Batı Trakya bırakılmış, bölüştürülmüştür (Featherstone, vd., 2011). Batı Trakya'nın dâhil olduğu Yunanistan ülkesi ise 1986 yll sonrasında, desantralizasyon uygulamasını yürürlüğe koymasıyla ayrıca 13 bölgeye ayrılmıştır. Bu yapılanma ile ülke, Doğu Makedonya-Trakya (Batı Trakya), Orta Makedonya, Batı Makedonya, Teselya, Epir, İyon Adaları, Batı Yunanistan, Orta Yunanistan, Peloponnese, Attica, Kuzey Ege, Güney Ege ve Girit bölgelerine ayrılır (Krispis, 2016). Çalışmanın ilgi alanını oluşturan Batı Trakya ise kendi içinde üç alt yönetim birimine ayrılmış durumdadır. Bunlar, İskeçe (merkezi İskeçe), Rodopi (merkezi Gümülcine) ve Evros (merkezi Dedeağaç). İskeçe’ye Mustafçova, Yeniköy, İnhanl, Yenice, Gökçeler, Ilıca, Kozluca ve Şinikova; Evros iline Sofulu, Dimetoka, Dedeağaç, Kumçiftliği ve son olarak Rodop’a Gümülcine, Şapçı, Kozlubekir, Susurköy, Sikeli, Maronya, Cambaz, Kavaklı, Yassıköy, Hemetli, Mehrikoz ve Arabacıköy gibi belediyeler bağlıdır.

Bölgenin birçok halka (Türk, Yunan, Pomak, Roman, Yahudi ve Ermeni) ev sahipliği yapmış olması, bu pay etme işlemini mecbur kılmaktadır. Tarihsel seyrine bakıldığında bölgenin sirasıyla Türklerin, Bulgarların ve Yunanlıların hâkimiyetine girdiği görülür (Alp, 1995). 400 ylllı bir Osmanlı yönetiminin ardından bölge, bir yanda Fransız devriminin kaçınılmaz etkileri, diğer yandan da İngiltere, Fransa ve Rusya gibi büyük güçlerin çabalarıyla 1830 yılında Yunanistan adıyla yeniden

\begin{tabular}{r|l} 
Adres & Address \\
RumeliDE Dil ve Edebiyat Arasturmalart Dergisi & RumeliDE
\end{tabular} Osmanağa Mahallesi, Mürver Çiçeği Sokak, No:14/8 Osmanağa Mahallesi, Mürver Çiçeği Sokak, No:14/8 Kadıköy - İSTANBUL / TÜRKIYE 34714 Kadıköy - ISTANBUL / TURKEY 34714 e-posta: editor@rumelide.com e-mail: editor@rumelide.com,

tel: +90 5057958124 , +90 2167730616 phone: +90 505 7958124, +90 2167730616 
Assimilation, forced forgetting (effacing cultural memory) and name change (special for toponymy) in Western Thrace / S. Adiloğlu (pp. 510-526)

kurgulanır (Hatipoğlu, 1997). Bugün bölge nüfusu, toplamda 350.ooo kişiden oluşurken, bu oranın sadece 150.00o’i Türk'tür ("demografi” başlıklı, abttf.org internet sitesi). Türk nüfusunun "150.000 kişi” olarak gösterilmesi, bölge Türkleri ve bölge tarihini bilenler için manidardır. Zira uzun yllar boyunca baskın bir nüfusu temsil eden Türkler, bilhassa Yunan hükümetinin izlediği politika ve uygulamalarla azınlık nüfusuna dönüşmüş durumdadır. Batı Trakya'daki Türk varlığına bakılacak olursa, Balkaç’ın aktarımına göre (2015), Türklerin Batı Trakya'daki varlığı, 1363 yılıyla tarihlendirilir ve bu tarih, bir anlamda Türk hâkimiyetinin süresini 650 yll olarak göstermek için de yeterlidir. Az bir farkla Öksüz (2015) ise Batı Trakya bölgesinin dört aylık (1878 yılı içinde, Ayastefanos ve Berlin Anlaşmaları arasında geçen süre) bir zaman dilimi dışarıda tutulursa, 1913 yılına kadar, 549 yıl boyunca Türk hâkimiyetinde bulunduğunu belirtir. Yazar çalışmasında (Öksüz, 2015:4680), Batı Trakya’nın 1913 yılında bölge Türklerinin hakları güvence altına alınma şartıyla Bulgaristan'a verildiğini, 1919 yılında ise bölge Türklerinin "Batı Trakya Devleti”ni kurduklarını ancak bu devletin, bir yılın sonunda Yunan ordusunun işgaliyle son bulduğunu aktarır. Bugün halen Yunanistan toprakları içerisinde bulunan Batı Trakya, 1920’li yıllardan beri aynı ülke yönetimi içerisindedir.

1923 Lozan Barış Antlaşması'yla birlikte bölge Türkleri, birer "Yunan vatandaşı" statüsünde ve aynı zamanda onlara has "azınlık hukuku"na tabi durumdadırlar (Hüseyinoğlu, 2015). Söz konusu Antlaşma sonrası, Batı Trakya'nın idari sınırları da netleşir ve buna göre, Yunanistan'ın kuzey doğu sınır bölgesi durumunda olan Batı Trakya $8580 \mathrm{~km}^{2}$ lik bir coğrafi alan olarak tanımlanır. Bölge, kuzeyde Rodop Dağları, batıda Nestos Nehri, güneyde Ege Denizi ve doğuda Meriç (Evros) Nehri ile çevrili bir alanı kapsar. Burada çalışmanın odaklandığı nokta itibariyle de önemli bölgelerinden birisi durumunda olan Rodop Dağlarıly ilgili küçük bir ekleme yapılabilir. Bu ihtiyaca binaen bölge, 100120 kilometre genişliğinde olup, 2000 metreden de fazla derin boğazları ve dar vadileriyle birbirinden ayrılan, erişilemez ve ulaşılamaz bir arazi sağlayan on tepesiyle bölgenin fiziki şartlarını ve doğal olarak gelişimini doğrudan etkilemektedir (Featherstone, vd., 2011).

Coğrafi ve idari anlamda yaşanan değişim, pek tabi bölge nüfusunun nicelik ve nitelik itibariyle de bir değişime uğramasına yol açar. Buna göre Osmanlı dönemi ve sonrasındaki ilk birkaç yll bölgede yoğun bir Türk nüfusuna rastlanırken, Yunan hükümetinin uygulamalarıyla baskın etnik nüfus olma özelliğini yitirmeye başlar, Yunan asıllı sakinler Batı Trakya nüfusuna göre daha kalabalık duruma gelir (Kamozawa, 1982). Yunan hükümetinin nüfus dengelerinde değişim yakalamaya yönelik uygulamalarının ardında bölgeyi Türklerden arındırma gayesi gizlidir. Bu hususla ilgili Batı Trakya'nın Sesi Dergisi'nin 30. sayısında yayınlanan bir haber metninde (1991), Batı Trakya Türkleri Dayanışma Derneği Genel Başkanı olan Tahsin Salihoğlu'nun bir demecine yer verilmektedir. Bu demecinde Salihoğlu, Yunanistan’ın izlediği politikanın “etnik kimliği imha”ya dönük olduğunu, sistemli ancak yavaş bir şekilde yürütülen asimilasyon politikalarının, 1991 yılı sonrasında hızlandırıldığını, yine benzer şekilde 1920'lerden önce Batı Trakya'da 500.ooo Türk'ün yaşadığını, bugünlerde ise bu oranın 150.000'e düştüğünü aktarmaktadır. Bu gayeye yönelik gerçekleşen girişimlerinse belli oranlarda başarıyla sonuçlandığı görülür. Zira 1923 yılı verilerinde Batı Trakya nüfusunun \%67'si Türklerden oluşurken bu oran, 1990’lı yıllarda \%40’a geriler (Alp, 1995:619).

Yunan hükümeti, bölgedeki “Türk” varlığını bir anlamda görünmez kılmaya yoğun bir çaba sarf eder2. Burada ayrıca bir parantez açmakta fayda vardır. Zira Yunan hükümeti sadece Türkleri değil Makedon,

Tabi buradaki ifadenin, eldeki kaynaklar göz önünde bulundurulduğunda oldukça yetersiz bir terime denk geldiği anlaşılır. Zira kaynaklardaki veriler, Yunan hükümetinin Türk nüfusunu azami düzeye indirmekle değil, yok saymakla meşgul olduklarını göstermektedir. Misal Batı Trakya’nın Sesi Dergisi’nde yayınlanan bir makalede (Altınsöz, 1988), "Yunan devlet yetkilisi açı seçik ‘Batı Trakya'da Türk yoktur' diyordu.” cümlesi ve bu cümleye karşı yapılan açıllamalar yer almaktadır.

Adres
RumeliDE Dil ve Edebiyat Araştırmaları Dergisi Osmanağa Mahallesi, Mürver Çiçeği Sokak, No:14/8 Kadıköy - ISTANBUL / TÜRKIYE 34714 e-posta: editor@rumelide.com tel: +90 $5057958124,+902167730616$
Address

RumeliDE Journal of Language and Literature Studies

Osmanağa Mahallesi, Mürver Çiçeği Sokak, No:14/8

Kadıköy - ISTANBUL / TURKEY 34714

e-mail: editor@rumelide.com,

phone: +90 $5057958124,+902167730616$ 
Arnavut, Bulgar, Ulah, Çingene, Yahudi, Giritli vd. azınlıkların varlığını da reddeder, bunları baskı yoluyla Helenleştirmeye çalışır ya da ülkeden göç etmelerini teşvik eder bir tutum sergiler (Alp, 1995). Yunan hükümeti bölgenin Türk varlığından hem nüfus hem de tarihi-kültürel izler itibariyle arındırılmasına odaklanır. Bu birçok aşaması olan uzun süreli bir projedir ancak temelde -veya en azından bu çalışmanın da doğrudan odaklandığı konuyla alakalı olan- iki yönü esaslıdır. Bunlardan ilki nüfus itibariyle Türk varlığını ortadan kaldırmaktır. Bunun için göç, ideal bir seçenektir. Bir diğeri de Bakirtzis ve arkadaşlarının (2014) da dikkat çektikleri gibi 1920 yılı ile birlikte Yunan hükümetinin bölgedeki tüm yerleşim yerlerini yeniden adlandırma çalışmalarıdır ki, bu stratejik bir hamle olup ülkelerin, yönetimlerin sıklıkla tercih ettikleri de bir uygulamadır.

\section{Batı Trakya'yı Yunan kılmada izlenen yol I: "göç”}

Göçün Batı Trakya Türkleri için anlamı, diğer Balkan ülkelerinde yaşayan (Bulgaristan, Makedonya, Kosova vd.) Türklerdekiyle benzerlik içerir. Buna göre doğup büyüdükleri yerlerden tamamen, eski yaşama geri dönmemek üzere kopup gitmek, kopup gönderilmektir. Daha da açık bir ifade ile "zorunlu" olarak göç etmektir. Bununla birlikte diğer Balkan ülkelerinden farklı olarak Batı Trakya'daki Türkler, göçün en yoğun halini Yunanistan ile Türkiye arasında yapılan mübadele ile yaşamıştır. Diğer bir fark ise zaten bu noktada ortaya çımaktadır. Zira onlar, yasalar nezdinde, içinde yer almadıkları bir mübadelenin bir parçası durumuna itilmişlerdir. Oysa "mübadele", Yunanistan sınırları içinde Batı Trakya bölgesi hariç diğer bölgelerdeki Türkleri kapsamış ancak onlarla birlikte ve sonrasında- Batı Trakya Türkleri de göç etmek mecburiyetinde kalmıştır.

Söz konusu mübadele, temelde "Yunan ve Türk Halklarının Mübadelesine İlişkin Sözleşme ve Protokol" adıyla tanımlanmış bir sözleşme olup ülkeler arası nüfus hareketliliğini anlatır. Nedenleri tartışma götürmekle birlikte en son aşamada iki ülkenin (burada Yunanistan ile Türkiye), karşllıklı anlaşması sonucu fiiliyata geçmiş ve bu anlaşma sonucu 350.000 Müslüman Türk ile 200.000 Hıristiyan Rum, yaşadıkları yerleri terk edip birer mübadil olarak iki ülke arasında yaşam yeri değişikliğine gitmişlerdir (Kayam, 1993). Pek tabi bu "yaşam yeri değişikliği” anlaşılacağı üzere keyfi değil, büyük bir zorlama ve zorunluluk sonucu yaşanmıştır. Ülke değişikliği yapacakların kimlerden oluşacağı konusu da yine büyük tartışmalar yaratmış ve en sonunda yasal bir zemine oturtularak kimlerin mübadil olacakları ve olmayacakları kararlaştırılmıştır. Hazırlanan sözleşmenin 2. Maddesi bu noktaya açıklık getirmek için oluşturulmuştur:

"1912 Yasası ile sinırlandırıldığı biçimde İstanbul Belediye [Şehremaneti] stnırları içinde 30 Ekim 1918 gününden önce yerleşmiş bulunan tüm Rumlar, İstanbul'da oturan Rumlar sayılacaklardir. 1913 Bükreş Antlaş̧masının saptamış olduğu sını çizgisinin doğusundaki bölgeye yerleşmiş tüm Müslümanlar, Batı Trakya'da oturan Müslümanlar sayılacaklardır."

Buna göre İstanbul'da yaşayan Rumlarla Batı Trakya'da yaşayan Müslüman Türkler bu mübadele süreci dışında bırakılmışlardır. Böylece Yunanistan'daki Müslüman ahali zorunlu göçe tabi tutulurken, bu süreçte Batı Trakya Müslümanları Yunanistan devleti içerisinde azınlık statüsünde birer vatandaş olarak yaşamlarını sürdürebileceklerdi (Alioğlu-Çakmak, 2018).

Azınlık statüsünde bir vatandaşlık hakkına sahip olmaları Batı Trakya Türklerinin, refah ve barış içinde bir hayat sürmeleri için yeterli olmaz. Yunan hükümeti, söz konusu Türklerin göçüne veya Yunan etnik kimliği içinde erimelerine çabalamıştır. Bu durumda bölge Türklerine düşen, iki yoldan birini seçmektir. Biri, çeşitli baskılara rağmen bölgede durup azınlık olarak yaşamayı sürdürmek, bir diğeri ise iltica etmek veya kaçak olarak Türkiye'ye göç etmektir (Öksüz, 2015:4682). Bu da onların

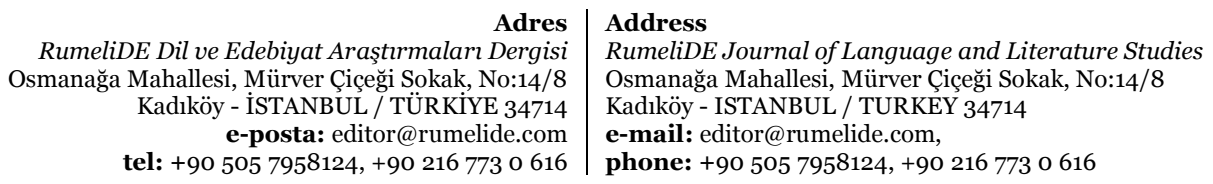


Assimilation, forced forgetting (effacing cultural memory) and name change (special for toponymy) in Western Thrace / S. Adiloğlu (pp. 510-526)

birer mübadil olarak olmasalar da birer muhacir veya birer göçmen olarak göç yollarına düşmelerini gerektirmiş ve hatta bunu zorunlu olarak yapmaları gerekmiştir. Öksüz'e göre (2015:4682), mübadele dışı tutulsalar da Batı Trakya Türkleri arasında göç eğiliminin başladığı, bu eğilimin gelişmesinde mübadele ile gelen Rumların3 Batı Trakya topraklarına yerleştirilmeleri ve topraklarına el konulması etkilidir4. Bu noktaya temas eden bir diğer kaynak (Sarı, 2015:32) ise bölgenin yayın organlarından Hakimiyet-i Milliye gazetesinde 7 Kasım 1923 yılında yayınlanan bir habere atıf yapar: “Karaağaç'tan Meriç'e dek uzayan sahadaki Türk köyleri göçe mecbur edildikten ve yerlerine Rumlar iskan olunduktan başka yeni Rum köyleri vücuda getirerek, o havalide Rum ırkını çoğaltılmasına çalş̧ılmakta..." Kandler (2007), 1923 yılı sonrasında ve de bilhassa Lozan Antlaşmasının sağlanmasından kısa bir süre sonra "hatırı sayılır miktarda tarımsal mülkün" yeniden dağıtılmasına başlandığını aktarır. Yazarın aktardığı bilgilerde, 1923-1924 yılları arasında Müslümanlara ait kentsel alanlardan 5.590 ve kırsal kesimden 8.245, mahallin, bölgeye yeni gelecek olan yeni vatandaşlar (Trakya’ya gelen mülteciler ile Küçük Asya'dan gelen Rumlar) için ele geçirildiği anlatılmaktadır.

Bölge Türklerinin temsilcilerinden biri olan Sadık Ahmet (2011) de benzer şekilde mübadele anlaşması gereği mübadele dışında bırakılan Türklerin, güvence altına alınan haklarına rağmen Yunan yönetimince farklı baskı ve uygulamalarla karşı karşıya bırakıldıklarını aktarır. Bunlardan en yoğun olarak uygulananları, Türkleri göçe zorlama, göç etmemeleri halinde asimile etme ve vatandaşlıktan çıkartmaktır. Göç etmek zorunda bırakılan Batı Trakya Türkleri, bir tarafta göçe itilirken, diğer tarafta ise istenmeyen bir pozisyonda kendilerini bulurlar. Zira göç etmeyi istedikleri ülke olan Türkiye, bölgede Türk nüfusunun korunabilmesi adına Batı Trakya'dan gelecek olanlara kapılarını kapatır. Ülkenin bilhassa 1920'li ve hatta 1930'lu yllardaki stratejisi bu yöndedir. Ancak Türkiye'nin Batı Trakya'dan göçmen kabul etmeyeceği bilgisine rağmen bölge Türkleri arasında bir kısmı mazeretleriyle birlikte Türk makamlarına sığınır, diğer bir kısmı ise farklı yollar deneyerek Türkiye’ye göç girişimini gerçekleştirir. Öksüz (2015:4687), Atina Telgraf Ajansının Anadolu Ajansı'na çektiği bir telgrafa yer vererek, bu telgrafta, Batı Trakya'dan 1932 yılında Türkiye'ye göç eden sayısını 27 olarak verdiğini aktarır. Genel olarak 1930'lu yıllarda düşük yoğunlukta göçler yaşansa da esas yoğunluk, II. Dünya Savaşı ve sonrasında kitlesel düzeye varan göçlerle yaşanmaya başlar. Yazar Öksüz’e göre (2015), II. Dünya Savaşı, Batı Trakya Türklerinin Türkiye'ye göçlerinde yeni bir sayfa açar, zira Alman orduları tüm Balkanlar’ı işgal edince Bulgarlar da Batı Trakya'yı ele geçirmiş olur. Bu işgal ister istemez bölge Türklerini korkuya ve sığınacak yer arayışına iter, çare Türkiye’ye göçtür. Bu süreçte Öksüz’ün (2015), 3 Ağustos 1959 tarihli Trakya Gazetesi'nden aktardığı verilere göre, 10.00o Batı Trakya Türkü Türkiye'ye göç eder. Tabi kitlevi göçler sadece bu tarih aralığıyla sınırlı olmaz, 1940'lı yıllarda da bölgenin ürettiği korku ve bezginlik, bölge Türklerini yine yollara döker. Öksüz (2015), Lozan ve Bat Trakya: 1913’te ilk Türk Cumhuriyeti isimli bir çalışmadan hareketle 1946-1949 tarihleri arasında serbest göçmen ve kaçak olarak Türkiye’ye sığınanların sayısını 17.793 kişi olarak aktarır.

1940'lı yllar bölge Türkleri için önemlidir, zira çete baskınlarının bölgede yoğun olarak yaşandığı bir döneme denk gelir. Öksüz (2015), bölge Türklerinin bir yandan Yunan hükümetine bağlı kuvvetlere karşı mücadele eden komünist çete mensuplarının saldırılarına maruz kaldıklarını diğer taraftan ise hükümet kuvvetleri ve sağcı çete üyelerinin tazyikinden kendilerini kurtaramadıklarını aktarır. Burada Öksüz’ün (2015:4691) dile getirdiği önemli bir nokta da Yunan hükümetinin çetelerle mücadelesinde

3 Bölgeye yerleştirilen Rumlarla ilgili ek bilgi Kandler (2007) şu bilgilere yer verir; Bölgeye gelenlerin göçü -Anadolu'dan gelen (Rumlar)- 1928 yılına kadar sürer ve göçlerle 110.000 kişi Batı Trakya’ya gelir. Böylesi bir akış ise bir anlamda Yunanistan'a “taze kan” olur ve ülkenin kuzeyindeki nüfusun homojenliğini artırıcı yönde etkide bulunur.

Alp (1995:617), bu konuyla ilgili haritalar üzerinden Batı Trakya'daki taşınır ve taşınmaz malların etnik azınlıklara göre aitlik düzeylerini ortaya koyar. Buna göre, 1920'li yıllarda Batı Trakya'daki malların \%86’sı Türklere, \%6'sı Rumlara ve \%1'i diğer unsurlara aittir.

RumeliDE Dil ve Edebiyat Araștırmaları Dergisi Osmanağa Mahallesi, Mürver Çiçeği Sokak, No:14/8 Kadıköy - ISTANBUL / TÜRKIYE 34714 e-posta: editor@rumelide.com tel: +90 $5057958124,+902167730616$
Address

RumeliDE Journal of Language and Literature Studies

Osmană̆a Mahallesi, Mürver Çiçeği Sokak, No:14/8

Kadıköy - ISTANBUL / TURKEY 34714

e-mail: editor@rumelide.com,

phone: +90 505 7958124, +90 2167730616 
Bulgaristan sınırına yakın ve Türklerin yoğun olarak yaşadıkları dağ köylerini boşaltma girişimleridir. $\mathrm{Bu}$ girişimler, ister istemez bu bölgelerde yaşayan Batı Trakya Türklerini yine benzer bir davranışa, Türkiye’ye doğru göçe itmiştir. Göç kadar, Batı Trakya Türk nüfusunu etkileyen bir husus da göç etmeyenlere dönük uygulamalardır.

\section{Göç ettirmeye dönük uygulamalar}

Batı Trakya Türklerini salt göçle eşleştirmek yetersiz bir girişimdir. Zira Yunan hükümeti, göçü birincil çözüm yolu olarak görmekle birlikte göçü tetiklemek adına ayrıca bir takım uygulamalara girişir. Baskın Oran (1986), Yunan yönetiminin Batı Trakya Türklerine yönelik uygulamalarını listeler: Ev veya bahçe duvarı gibi küçük sıva işleri dahi onarımına veya tamirine izin verilmeyişi bunlara küçük bir örnektir. Diğer uygulamalar arasında ise tarımcı olmaları ve traktör kullanmaya gereksinimi olmalarına rağmen traktör ehliyetinin verilmeyişi, av silahları ve ruhsatlarının ellerinden alınışı ve geri verilmeyişi, yurttaşlıktan çıkarılmaları, her firsatta ve üst sınırdan para cezasına çarptırılmaları, tahrikler ve/veya polis-jandarma baskısına maruz kalmaları gösterilebilir.

Bir diğer örnekte (Öksüz, 2015), göç etme eğiliminde olan halkın göç etme nedenleri aktarılarak söz konusu uygulamalara değinilir. Bu çalışmada, Batı Trakya'daki Türklerin göç etme nedenlerinin öğrenilmesi maksadıyla Türkiye hükümeti tarafından görevlendirilen ve yaptığı araştırmalar sonucu bir rapor oluşturan Türkiye'nin Atina Elçiliği üçüncü kâtibi M. Recep Bey’in açılamaları paylaşılır. 1934 yılı sonlarında artan kitlevi göçlere dair kâtip Recep Bey, üç aylık bir zaman diliminde bölgeden 700 ve belki de fazla sayıda Türk’ün göç ettiğini aktarır. Kâtip Recep Bey’e göre (akt. Öksöz, 2015), bölge Türklerinin göç etme nedenleri arasında birçok etmen vardır, bunlar arasında, Yunan Hükümeti’nin büyük çiftlikleri satın aldığı, Türk köylüsünü arazisiz bıraktığı, Rum göçmenlerin Türklere ait arazi ve harman yerlerini işgal ettikleri, ekinleri ateşe verdikleri, tehdit, sövme ve bıçaklama gibi eylemlerde bulundukları bilgisini paylaşır.

Yakın tarihli bir rapor (Verhas, 2019) incelendiğinde Yunan hükümetinin 1900’lü yılların başlarındaki uygulamaların benzeri nitelikte denebilecek uygulamaları halen dönem dönem sürdürmekte olduğunu ortaya koyar. Bu uygulamalardan biri, "Türk" adını taşıyan azınlık derneklerinin kaydettirilmemesi ve hatta feshedilmesidir ki, bu süreçte birçok Türk derneği (1927 yılında kurulan Gümülcine Tük Gençlik Birliği, 1328 yılında kurulan Batı Trakya Türk Öğretmenleri Birliği) tasfiye edilmiştir (Verhas, 2019:6). Kronolojik olarak bakıldığında, Türk adının dernek isimlerinden kaldırılması, 1970 yılına denk gelir. 1972 yılı ile birlikte "Türk Okulu" ifadesi, "Azınlık Okulu" olarak kullanılmaya başlanır, yine aynı tarihte hükümetin genelgesiyle okul isimlerinden "Türk" kelimesi kaldırılır. Sadece "Türk" ismi değil, 1260 sayılı yasa ile Türkçe yer isimlerinin haberleşme, yazışma, basın ve örgütlerde kullanımının da yine aynı tarihte (1972) yasaklandığı görülür (“kronoloji” konusunda bkz. batitrakya.org). Türk adına yönelik uygulamalara ilaveten bir diğer uygulama da başta dinî haklar olmak üzere bölge Türklerine özgü hakların yapılan antlaşmalarla garanti altına alınmasına rağmen uygulanmasına müsaade edilmeyişidir. Misal, siyasi bir takım çıkarlar uğruna bölge Türklerinin "vatandaşlıktan iskat/çıkarma" uygulamasıyla yüz yüze kalmalarıdır. Esas amacın Türk nüfusunu azaltmak olduğunu anlatan Ahmet (1995), bu gayeyle yurt dışında öğrenci veya işçi olan, Yunan ordusunda askerlik yapan, Yunanistan’ın bir bölgesinde çalışan veya Türkiye'de geçici olarak ikamet eden çok sayıda Türkün vatandaşlıktan çıartıldıklarını aktarır. Aynı konuya temas eden Alp (1995), Batı Trakya'daki Türk nüfusunu azaltmak maksadıyla Yunan yönetiminin farklı bir uygulamaya gittiğini, seyahat amacıyla ülkeden giden soydaşları (bölge Türklerini) çeşitli bahanelerle vatandaşlıktan çıkarttığını aktarmaktadır. Yine aynı kaynakta (Alp, 1995:631), "Grek etnik kökenli olmayan bir kimse, geri dönmemek niyetiyle

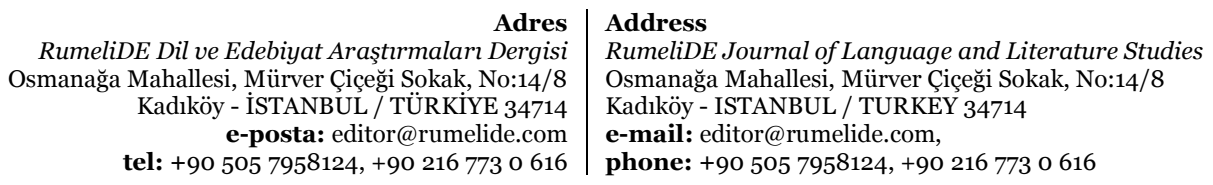


Assimilation, forced forgetting (effacing cultural memory) and name change (special for toponymy) in Western Thrace / S. Adiloğlu (pp. 510-526)

Yunanistan'ı terk ettiği takdirde, Yunan vatandaşlığını kaybetmiş ilan olunabilir. Bu aynı zamanda yurtdışında doğan ve ikamet eden Grek etnik kökenli olmayan bir kimse için de geçerlidir...” şeklinde hazırlanmış Vatandaşlık Kanunu'nun 19. Maddesi'ne yer verilmektedir. Bu maddeyle vatandaşlıktan çıkarılanlar ise vatandaşlıktan çıkarıldıklarını bilmeyen Batı Trakya Türkleridir. Bunlar, 1988'de 122, 1990'da 66, 1991 yılında 544 kişiden oluşur ${ }_{5}$ ve çoğu Türkiye, ABD ve Almanya'ya eğitim amacıyla giden Türk öğrencilerinden teşekkül etmektedir. Sonuç itibariyle 1955 ila 1998 yılları arasında ister Yunanistan sınırları içerisinde olsun, isterse de Yunanistan sınırları dışında olsun, Yunan Vatandaşlık Yasası'nın 19. Maddesi gereği, Yunanistan uyruklu 60.00o civarında Müslüman Türkü, vatandaşlıktan çıkartmıştır (Cin, 2009: 165).6

Daha güncel tarihlerdeki uygulamalara bakıldığında "1973-74" yıllarını da bu bağlamda ele almak önemlidir. Hatırlanacağı üzere Kıbrıs Barış Harekâtı ile Türkiye'nin Kıbrıs'a askerî harekât düzenlemesi, Yunanistan'da yönetimi elinde bulunduran cuntanın devrilmesi ve Konstantin Karamanlis başkanlığında yeni bir hükümetin kurulmasını mümkün kılmıştır. Dolayısıyla bu tarih veya harekât, sadece Kıbrıs'taki Türkleri değil Yunanistan'daki Yunan ve Türkleri de ilgilendirmiştir. Harekât, Kıbrıs Meselesi'nin bir sonucudur, harekât öncesi ise geniş bir bölgede Türklere baskılar artmıştır. Bu baskılara örnek olması açısından, Türkiye radyolarının dinlenmemesi ve Türkçe plakların çalınmaması için Narlıköy, Kozlukebir ve Şapçı gibi Türk nüfusunun yoğun olduğu köy ve kasabalarda Yunan polisi tarafından aramalar yapmış olduğu bilgisi aktarılabilir (Gülmez ve Akdeniz, 2015:4789).

Tüm bu ve benzeri uygulamalar sonucunda bölgedeki Türkler, "150.00o kişi”lik bir nüfusa kadar geriler. Coğrafi dağılımlarına bakıldığında Türklerin, yoğun olarak, Rodop (toplam nüfusun \%55’i civarında) ve İskeçe (toplam nüfusun \%45’i) bölgelerinde, az bir oranda (\%10’u) ise Meriç bölgesinde yaşadıkları anlaşılır (Verhas, 2019:3). Kentsel alanlara nazaran kırsal alanlarda yaşayan bölge Türkleri, nüfus itibariyle çoğunlukta olduğu köylerde ve farklı etnik grupların da bulunduğu karma yörelerde yaşamaktadırlar (Verhas, 2019:3). Bu noktada Yunanistan'a bağlı 13 bölge içerisinde Batı Trakya'nın ülkenin, "gelişmemiş bölgesi” olarak kabul görüldüğü belirtilmelidir (Serdar, 2014:101). Bölgenin gelişmemişliği ve buna ilaveten en fakir bölge oluşunu ise pek tabi Yunan makamlarının kasıtlı ihmalleriyle bağlantılıdır (Bahcheli, 2007).

Toprağın işlenişi ve dolayısıyla ekonomik getirisiyle ilgili yaşanan sorunlara ilaveten bölge Türkleri sahip oldukları topraklarla ilgili de önemli bir sorunla yüz yüzedir. Zira arazileri, "kamulaştırılma" söylemi üzerinden farklı zaman aralıklarında ellerinden alınmaktadır. Konuyla ilgili olarak Alp (1995), Anadolu'dan getirilen Rumların Batı Trakya'da kamulaştırılan topraklara yerleştirildiğini ve bu sayede Türklerin yaşadıkları bölgelerde Rum köylerinin kurulduğunu anlatır. Ona göre (Alp, 1995:629), Batı Trakya'da kamulaştırılan topraklar üzerinde 572 Rum köyü kurulmuştur. Bununla birlikte açık hava hapishaneleri, yol, askeri bölge yapımı gibi gerekçelerle arazilere el konulduğu anlaşllır. Örneğin, Baltalı hazırladığı raporda (2009), Gümülcine'de sanayi bölgesi inşa edileceği gerekçesiyle, 1978 ylında Yahyabeyli (Yun. Amaranda), Vakıf (Vakos), Kafkaskoy (Trilorion), Ambarköy (Pamforo), Seymen (Filakas) köylerine ait 4000 dönüm arazinin zorla kamulaştırıldığını, 1979 yılındaki kamulaştırmada ise 4300 dönümlük tarım arazisinin, askeri tatbikatlarda kullanılacağı gerekçesiyle el değiştirdiğini yazar. Bununla da yetinmeyen Yunan hükümetinin 1980 yllında Gümülcine’ye bağlı

1991 tarihli Batı Trakya'nın Sesi Dergisi'nin 30. Sayısı (bkz. batitrakya.org) vatandaşlıktan çıkarılan 544 Batı Trakya Türk'üne eğilmiş, bölge bölge kimlerin vatandaşlıktan çıkarıldığını sayfalarca yazmıştır. Çalışmanın araştırma sahası durumunda olan Yassıköy'den de bu süreçte 26 kişinin vatandaşlıktan çıkarıldı ğı görülmektedir.

$6 \quad$ Burada ayrıca bir noktaya temas etmekte fayda vardır, vatandasllı̆̆ tekrar kazanma süreci yavas ve yorucu bir süreçtir (Ayhan, 2014). Dolayısıyla vatandaşlıktan çıkartma ne ölçüde kolay ve hızlı şekilde gerçekleşmişse vatandaşlı̆̆ tekrar kazanma süreci bir o kadar zorlu ve sorunlu olmuştur.

Adres

RumeliDE Dil ve Edebiyat Araștırmaları Dergisi Osmanağa Mahallesi, Mürver Ciçeği Sokak, No:14/8 Kadıköy - ISTANBUL / TÜRKIYE 34714 e-posta: editor@rumelide.com tel: +90 $5057958124,+902167730616$
Address

RumeliDE Journal of Language and Literature Studies

Osmanağa Mahallesi, Mürver Çiçeği Sokak, No:14/8

Kadıköy - ISTANBUL / TURKEY 34714

e-mail: editor@rumelide.com

phone: +90 505 7958124, +90 2167730616 
Esekçili (Thamna), Ayazma (Agiasma), Gebecili (Rizoma), Bulatköy (Asomatoi) köylerine ait 3200 dönümlük araziyi, Trakya Dimokritos Üniversitesi için 1980 yılında kamulaştırdığını ekler. Buradaki örnekler salt Gümülcine için geçerlidir, yoksa Batı Trakya bölgesinin büyük bir bölümünü kapsar şekilde kamulaştırmaların yapıldığı yine Baltalı'nın çalışmasında yer alır. Bu noktada, "kamulaştırma" faaliyetinin ne denli ciddi ve geniş ölçekli olduğunu anlayabilmek adına Acaroğlu'nun (2006) veri paylaşımına bakmakta fayda vardır. Yazar Acaroğlu çalışmasında (2006), tek tek bölgeleri içerir şekilde kamulaştırılan Türk arazilerini kır, bucak, çiftlik ve hatta mezarlık alanlar şeklinde7 sıralar. Ballı-hor (Vrava veya Vragia), Basırlı (Pasos), Bıyıklı-Osman (Mistakas), Çalabı-köy (Smigade), Çiftlikköy, Değirmen-dere (Darmeni), Dolapçılar (Strofi), Domru-köy (Domri veya Dokos), Dur-Hasanlar (Neda), Dündarlı veya Dondurlu (Drosia), Eşek-dere (Esoh), Evren (Evrenos), Hacı, Hacı-Mustafa (Amfia), Ircan veya Ağrı-can (Arisvi), Karaca-oğlan (Aratos), Kızıl-ağaç (Regada), Kızıllar (Kizarion), Kozlu-kebir (Arriana), Kurcalı veya Kırcalı (Likion), Küçük-Müslim (Mikro-piston), Küçük-sirkeli (Agra veya Mikro-Ksidia), Menetler (Skaloma), Payamlar (Plagia), Sinır-dere (Nevra), Taşkınlar (Kinira), Üç-gaziler (nikite), Vakıf (Vakos) ve Yeni-köy (Geneti veya Yeneti) köyleri kamulaştırılan 30 Türk köyüne örnektir. Bunlara ilaveten Acaroğlu, 30 köyden farklı olarak ayrıca kamulaştırılan köylere de çalışmasında yer verir. Ona göre, Yassı-höyük (Yasmos), Palazlı (Paladion), Çepelli (Agiasa) köylerindeki kamulaştırmayla birlikte Ayazma'da (Aigasma) 650 dönümlük arazisi, Deli-naz'da (Dilina) 3000 dönümlük arazisi, Eşekçili'de (Thamna) 1700 dönümlük toprak ve Gebecili'de (Rizoma) 600 dönümlük arazi benzer gerekçelerle kamulaştırılmıştır. Bu kamulaştırmaların sonucunda ise her biri Türk yerleşim birimi olan köylerin isimleri haritadan silinmiştir (Acaroğlu, 2006:248-572). Dolayısıyla kamulaştırma eylemi, salt büyük bir alandaki toprağın el değiştirilmesine değil aynı zamanda çok sayıda Türkçe yer isminin de ortadan kaldırılmasına yol açar.

\section{Batı Trakya'yı Yunan kılmada izlenen yol II: "unutma"}

Batı Trakya topraklarının Osmanlı Devleti ile tanışıklığı tarihi, kültürel ve demografik kanıtlardan okunabileceği gibi her an karşlaş̧labilir olan yer isimleriyle de pek ala fark edilebilmektedir. Her ne kadar bugün Batı Trakya'daki Türkçe yer isimlerinin yerini, Yunanca birer muadil isim almış olsa da bölge, halen Türkçe yer isimleriyle anılagelmektedir. Yer isimlerindeki bu değişim, salt Batı Trakya’ya özgü olmayıp, Balkanların birçok ülkesinde ve hatta dünyanın çoğu bölgesinde de karşılaşlabilir uygulamalar arasındadır. Zira kimliklerin değişimi, beraberinde çoğunlukla bölgelerin/yerleşim yerlerinin de alışlagelmiş isimlerini değişime uğratmaktadır.

Yer isimleri konusunda Paul Connerton'un iddia ve örnekleri enteresandır ve bir o kadar da anlaml. Yazar (Connerton, 2014:20), cümlelerine insanlar gibi yerlerin de birer isme sahip ve evrensel oldukları iddiasıyla başlar. Ona göre, bir yer isminin bahsi geçmesi bile bilinen bir hikâyeyi kısa ve öz bir biçimde anlatmasına yetecektir. Ki, yer isimlerine duyulan hassasiyetin nedeni de zaten her hâlükârda kısa ve öz biçimde hikâyesini açığa çıkarma, hikâyesini hafızaya taşıyabilme marifetinde gizlidir. Connerton, bu türdeki isimlere duyulan hassasiyetin yeni olmadığını, tarih sahnesi içinde çoğu kez ve farklı ülkelerce sergilendiğini belirtir. Örnek olarak İngilizce yer isimlerini verir ve bu isimlerin, sömürgeciliğin ve işgallerin güzergâhını takip eden bir yapı sergilediğini anlatır. Bununla da yetinmez, İngiltere özelinde, 10. yüzyılda ülkenin kuzey batı bölgelerine yerleşmiş Norveçlilerin kendilerinden geriye bıraktıkları şeyin, yaşadıkları bölgelere verdikleri isimler olduğunu aktarır. Yer isimleri

Ki burada Acaroğlu, sadece köylerin değil, bucak, çiftlik ve hatta mezarlıkların dahi kamulaştırma adı altında devralındığı bilgisini paylaşır. Konuyla ilgili Baltalı (2009), 1931 yllında çizilen Gümülcine Şehir Planımın, Osmanlı döneminden kalma 20'den fazla cami ve vakıf arazilerini kapsadığını, buna bağlı olarak birçok cami, mescit, vakıf arazisi, mezarlık ve okul binalarının sahip oldukları mülklerinden kısımlar kaybetmeleri anlamına geldiğini aktarır.

Adres $\mid$ Address

RumeliDE Dil ve Edebiyat Araşttrmaları Dergisi $\quad$ RumeliDE Journal of Language and Literature Studies Osmanağa Mahallesi, Mürver Çiçeği Sokak, No:14/8 Osmanağa Mahallesi, Mürver Çiçeği Sokak, No:14/8 Kadıköy - İSTANBUL / TÜRKIYE 34714 Kadıköy - ISTANBUL / TURKEY 34714 e-posta: editor@rumelide.com e-mail: editor@rumelide.com, tel: +90 505 7958124, +90 2167730616 phone: +90 505 7958124, +90 2167730616 
Assimilation, forced forgetting (effacing cultural memory) and name change (special for toponymy) in Western Thrace / S. Adiloğlu (pp. 510-526)

konusunda Connerton (2014), geçmiş deneyimlere bakmakla birlikte güncel duruma da eğilir ve bu çağda yerlere verilen isimlerin, seçici bir davranışa dönüştüğünü ve bilhassa hatırlanması istenen anılara dönük isimlerin seçildiğini ekler.

Hemen hemen benzer bir noktaya temas eder şekilde Kulavkova (2012) da yer isimlerinin (veya akademik bir terimle toponimis), salt dilsel değil, aynı zamanda medeniyetin, ulusların ve insanlı̆̆ın hafızasının birer parçası olduğu fikrini paylaşır. Bununla birlikte bölgeye/bölgelere dair doğal özellikleri, tarihi olayları, ekonomik ve arazi kullanımı, eski feodal ilişkileri ve yerleşim yerinin tarihi özelliklerini yansıtması bakımından da gereklidir (Jordan, 2012). Burada unutulmaması gerekli olan husus şudur ki, yer isimleri veya bölgeleri isimlendirme faaliyetinin hiç de sanıldı̆̆ı gibi masum bir uğraş olmadığıdır. Zira bu faaliyetler, birçok kimliksel, siyasi, idari ve yönetsel çıkarların çarpıştı̆̆ı çetrefilli ilişkilerin bir gereğidir. Kimi durumda, "coğrafi isim savaşı" olarak telaffuz edilebilecek sonuçları olan ve aynı zamanda bir takım toponimik-politik stresler üretebilecek coğrafi bölgelerden de söz edilmektedir (Kadmon, 2004). Bu noktada yazar Kadmon'a göre, Kıbrıs, coğrafi isim savaşının patlak verdiği bölgelerdendir. Benzer patlamalar, farklı ülke ve bölge örneklerinden de gelebilir. Ancak burada esas mesele, patlak veren bu coğrafi isim savaşlarının nedenleridir. Her şeyden önce böylesi bir davranışın veya sonucun oluşmasında, bölge otoritesinin "el değiştirmesi” etkilidir. Bir başka ifade ile coğrafi bir bölgenin ele geçirilmesi durumunda her yeni yönetimin yapacağı veya atacağı adımlar arasında bölgede kabul görmüş yer isimlerinin o anki baskın etnik dile çevrilmesi veya yeniden adlandırılması girişimidir. Bu da yeniden adlandırma girişiminin/girişimlerinin ister istemez politik birer eylem olarak tanımlanmasını beraberinde getirmektedir.

Kadmon (2004), ülkelerin, kendi dönemlerinden önceki yönetimlere veya etnik aidiyetlere ait coğrafi bölgelerin kendi yönetimleri döneminde değişmeye açıldığını ve zamanla mevcut toponimlerin devrilmeye/dönüşmeye başladığını aktarır. Burada yine Kulavkova'ya dönmekte fayda vardır, yazar yer adlarının ülkelerce korunduğunu ve korunmasına yönelik yeri geldiğinde uluslararası düzeyde uygulamalarla yer isimlerinin muhafaza edildiğini aktarır. Pek tabi yer isimlerinin korunması çabası, ancak baskın grubun (medeniyet veya kültürün) kendi (veya atalarının) yaratımı olması halinde geçerlidir. Bir başkasına, ötekine ait olması durumunda ise yer isimlerinin değişimi kaçınılmazdır. Kulavkova (2012), Makedon yer adlarındaki zorunlu dönüşümü ele aldığı çalışmasında, değiştirilmeye çalışılan Makedon yer isimlerinin olduğu gibi muhafaza edilmeleri gerektiğini vurgular. Bununla birlikte, yerel halkın kabul etmesi durumunda yer isimlerinin kültürel miras olarak muhafaza edilmesini de önerir. Yabancı yer isimleriyle ilgili olarak Kulavkova (2012), onların katmanlı tarih ve kültürün biçimsel ve anlamsal göstergeleri olarak hizmet ettiklerini ve ayrıca bir dilin içindeki bir dili, bir dünya içindeki bir dünyayı belli bir sosyal gerçeklik içinde sunduklarını aktarır. Yazar (Kulavkova, 2012) bu durumda yani mevcut yer isimlerinin ortadan kaldırılmaları durumunda ise tarihsel izlerin silinecek oluşundan dolayı üsluptan, ruhtan, karakterden, kaderden ve tarihten yoksun "yaşayan ölü (zombi) alanlar"la sonuçlanacak bir sürecin yaşanacağını aktarır. Bu iddiaya rağmen yer isimlerinde değişikliklerin (veya bir başka ifade ile yeniden isimlendirmenin) yaşandığı da bir gerçektir ve bu gerçeğin altında politik gayelerin olduğu apaçık ortadadır. Bu noktada Jordan (2012), isimlendirmeyi, bir yerin kimliğini tanımlama gücüne sahip olmakla eşitler, bununla da yetinmeyip, yer isimlerinin olduğu tabelalarda ikinci bir ismin (farkh bir dilde yazılmış olan da dâhil) bu yerin çift kimliğe sahip olduğunu ve tek bir grubun kontrolünde olmadığını göstereceğini aktarır. Bu iddiayla birlikte bir diğer iddia ise Pinchevski ve Torgovnik'in çalışmalarında (2002:365) George Orwell'ın "Geçmişi kontrol eden, geleceği kontrol eder. Geleceği kontrol eden, geçmişi kontrol eder.” şeklinde söylediği (veya

Tekin boyutta toponimi, dilbilim içerisinde özel isimleri inceleyen bir bilim dalı olan onomastik disiplinde yer alan bir alt bölüm olarak görülmektedir (Neethling, 2016).

Adres

RumeliDE Dil ve Edebiyat Araştırmalar Dergisi Osmanağa Mahallesi, Mürver Çiçeği Sokak, No:14/8 Kadıköy - İSTANBUL / TÜRKIYE 34714 e-posta: editor@rumelide.com tel: +90 505 7958124, +90 216773 o 616
Address

RumeliDE Journal of Language and Literature Studies

Osmanağa Mahallesi, Mürver Çiçeği Sokak, No:14/8

Kadıköy - ISTANBUL / TURKEY 34714

e-mail: editor@rumelide.com,

phone: +90 505 7958124, +90 216773 o 616 
yazdığı) bir cümlesine yaptıkları alıntıda gizlidir. Bu alıntıya göre, bugünü ve geleceği kontrol edebilmenin yolu geçmişi kontrol etmekten geçer. Geçmişin kontrolü ise ister istemez geçmişin bir takım izlerini unutturmaktan ve geçmişi yeni izlerle şekillendirmekten geçer.

Geçmişi hatırlatmaktan öte geçmişi üzerinde barındıran yer adları da bu noktada ülkelerin, yönetimlerin bugünü ve geleceği kontrol etme gayelerinde dönüştürmeye uğraşacakları ilk hedeflerdendir. Zira yeri tanımlayan isimler, ister istemez bugünden bağımsız geçmiş bir anda birileri (şu anki yönetici veya baskın gruba mensup olmayanlar) tarafından seçilmiş, kullanılmış ve halen de kullanılıyor olabilmektedir ve her kullanımlarında, kişilere/toplumlara, geçmişi/geçmişlerini hatırlatabilmektedir. Bu işlevleriyle yer isimleri Ground'un çalışmasında (2001), kamusal belleği büyük ölçüde etkileyen birer "sembolik anıt", De Souza'nın çalışmasında (2015) ise "dilbilimsel birer kalıntı” olarak tanımlanmaktadır. Yazar (De Souza, 2015), kimi durumda coğrafi anlamda bir varlı̆̆ı kalmamış olan coğrafi bölgelerin (veya bölge ayrımlarının, buna yönetsel sınırları da dâhil etmek mümkündür) gündelik hayatta ve zihinlerde mevcudiyetini koruyabileceği iddiasındadır. Bu iddiasına ilaveten yazar, bölge isimlerinin özellikleri ortadan kalksa bile alanı tanımlama, tekilleştirme ve anlam sağlama kapasitesine sahip olabileceğini aktarır.

Osmanlı hâkimiyeti sonrası Yunanistan yönetimine kalan Batı Trakya bölgesinin Yunan hükümeti tarafından (Yunancaya tercüme edilmesi dâhil) yeniden adlandırılması girişimi de bu nitelikte bir uğraştır. Tabi bu paragraftaki "uğraş" vurgusu doğrudan, Türkçe yer isimlerinin Yunancaya dönüştürülmesini anlatır ancak bir boyutu daha vardır ki, bu da yer adları envanteri denebilecek çalışmalarla ilişkilidir. Bu noktada bir parantez açmakta fayda vardır. Zira Güvenç’in aktardığı bilgilere göre (2014:V) Yunanistan yer adlarında değişiklik konusunu 1909 yılı ile birlikte gündeme taşır, buna yönelik komisyon kurar ve genelge hazırlayarak yer adı değişikliklerini gerçekleştirmeye odaklanır. Bunun için yönetim, "yayımladığı bir genelge ile Yunanistan'daki köy ve kasabaların yabancı adlarının Yunancaları ile değiştirilmesine karar verildiğini ilan eder.” (Güvenç, 2014) Ancak karar, yayımlandığı gibi uygulamaya dönüşemez, gerçekleşebilmesi bilhassa Türk-Yunan nüfus mübadelesi sonrasındaki (bilhassa 1926) yıllarda olur. Yazar Güvenç’in hazırladığı derlemede (2014:VI) Yunanistan Ulusal Toponomi Komisyonu kararı doğrultusunda yapılan hızlı ve yoğun çalışmalar sonucu mevcut yerleşim yerlerinin \%78'inin adının değiştirildiği iddiasındadır. Burada belirtilmesi gerekli bir husus ise yer adı değişikliklerinin uygulama sırasında ve sonrasında sorunlar yarattığı gerçeğidir. Yunan makamları açısından yer adı değişikliği (bilhassa önceki haline uyarlanmış Yunanca versiyonunda) çözümleme noktasında problemler yaratır. Zira Konortas'ın (2013) belirtiği gibi ülkenin aşması gereken birkaç zorluğu bulunur. Bunların başında olayın/bölgenin çözümlenmesinde bilinmesi gerekli dilin (Yunanca, Bulgarca veya Osmanlı Türkçesi gibi) yeterince bilinmiyor oluşu ve kaynaklardaki deformasyonlardır, bu da toponimlerin (yer isimleri) farklı farklı okunmalarına neden olmaktadır. Diğer yanda ise Türkçeden eser kalmamış yer adıyla bölgenin (köy ve/veya kasabanın) önceki sakinlerine yabancılaşmasıdır. Güvenç (2014:VI-VII) burada önemli bir noktaya temas eder ve der ki, çocuk yaşta terk etmek zorunda kaldıkları toprakları dünya gözüyle bir kez daha görmek isteyenlerin hesaba katmadıkları sorun, gidilip görülecek yerleşim yeri adlarını haritada bulamayacak olmaları, köy ve kentlerin adlarının değiştirilmiş olmasıdır. Yapılan değişikliğin Türkçe aslından farklı olmasının yanında Türkçe olanların transkripsiyonunda gerek telaffuz gerekse alfabe değişikliği nedeniyle de önemli yanlışlıklar yapıldığı anlaşılır ve bu da ister istemez eski ve yeni yer isimleri arasında bir kıyas veya ilişkinin kurulabilmesinin önünde büyük bir engele dönüşür. 
Assimilation, forced forgetting (effacing cultural memory) and name change (special for toponymy) in Western Thrace / S. Adiloğlu (pp. 510-526)

Yer isimleri anlamında ülke genelinde hâlihazırda kaç yerleşim yerinde isim değiştirme uygulamasına gidildiği konusunda kapsamlı bir veri yokturg. Bu yoksunluğun başlıca nedeni ise Hacısailoğlu ve Özcan'ın dile getirdikleri gibi (2013:1330), Yunanistan'da azınlı dillerindeki yer adları konusunun tabu olma konumunu muhafaza ediyor olmasıdır. Buna bağlı olarak mevcut ve değiştirilmiş Türkçe yer adlarıyla ilgili erişilebilir, yekpare ve kapsamlı veriye ulaşmak sıkıntılıdır. Ancak yeniden adlandırmaya yönelik kararların alındığıyla ilgili kimi kaynakta bilgiler mevcuttur. Misal, Bakirtzis, Ioannis ve Constantinides (2014: 21), 109298 numaralı bir karardan bahsederler. Bahse konu olan bu kararın, 2. Cilt, Sayı 1 ile Resmi Gazetede yayınlandığını ve bu kararla da bölgedeki isimlerin değiştirildiğini aktarmaktadırlar. Bununla birlikte yazarlar (Bakirtzis, Ioannis ve Constantinides, 2014), böylesi bir girişimin yukarıda yer alan yazarların açıklamalarında olduğu gibi Yunan hükümetinin yaptığı eylemin de "oldukça politik bir eylem" ve aceleyle alınmış bir karar olduğunu belirtmektedirler. Batı Trakya özelindeki duruma bakıldığında adına ne denirse densin ister sembolik anıt, isterse de birer kalıntı densin, bölgede çok sayıda Türkçe yer isminin bulunduğu anlaşılır. Yunan hükümetinin bakış açısından farklı olarak bölge Türkleri için Türkçe yer isim mevcudiyeti, kültürel ve tarihsel bir birikimin de göstergesidir. Değirmendereli (1993) Batı Trakya’yı esas alarak bu konuya şu sözlerle dâhil olur:

Yunanistan toprakların karış karış gezip dolaşanların, her yerde ve her zaman Türklerle ve Türk adını taşıyan yer, ova, orman, dağ, tepe, bayır, bahçe, ırmak, nehir, sahil, körfez, göç, köprü, çeşme vd. ile karşılaşırlar. [...] Diğer deyimle, Yunanistan'da her şeyde, şehir ve köylerden başlayarak, ova ve ormanlarına, saray ve kervansaraylarına varmcaya kadar Türklüğe ait tarihi bir geçmişin mühürü vardır.

Değirmendereli'nin "mühür" dediği hususa, Halit Eren (1988), “damga” demektedir ve o da benzer şekilde Rumeli’nin her köşesinde olduğu gibi Batı Trakya'da Türk-İslam damgasının varlığını koruduğunu ve damganın en somut örneğinin ("en müşahhas belgesi") de yer adlarında görülebileceğini anlatır. Eren (1988), tepesi, dağı, ovası, deresiyle her karış toprağında Türk'ün yer aldığını belirtir. Her iki yazar için bölgedeki Türk varlığı ve bu varlığı sembolize eden unsurların tümü, bir övünç kaynağıyken farklı etnik gruplar için aynı anlamlar üretemez. Örneğin, Değirmendereli çalışmasında (1993), Rus Generali Carnaev Car Aleksi'ye ve onun bir ifadesine yer verir. General için Türklerden kalan "silinmez hatıralar"ın yok edilmesi elzemdir, zira ona göre, ölümden korkmayanlar dahi bu hatıralardan korkmaktadırlar. Bir korku veya strateji, adına ne denirse densin Yunan hükümeti bu tavrı hızlıca gerçeğe dönüştürmüş, yer isimlerini değiştirmeye başlamıştır. Bu noktada Kandler (2007), 1923'ten sonra Osmanlıca olan yer isimlerinin ya değiştirildiğini ya da eski Yunan isimlerine geri çevrildiğini aktarır. Buna örnek olarak Gümülcine’nin Komotini, Sapçı’nın Sappes, Sendelli’nin Dymi’ye dönüştürüldüğünü ya da “Küçük Asya'dan” gelen göçmenlerin ait oldukları topluluk isimlerinin (İstanbul'daki Fener'den Fanari) veya yeni isimlerin (Rize'ye yakın Zanta'dan Nea Zanta gibi) verildiğini yazar. Kandler’in tarihlendirmesinden farklı olaraksa Hacısağloğlu ile Özcan (2013: 1333), Yunanistan'ın bağımsızlıkla birlikte yer adlarında değişime gittiğini, ülkenin 1830’lu yıllardan itibaren yer adlarını Yunancalaştırdığını aktarırlar.

Batı Trakya'daki tüm köy isimleri Yunanca isimlerle değiştirilmiş, Türkçe yer isimlerinin resmi amaçlarla kullanılması para cezası veya hapis cezasına varan uygulamalarla engellenmiş, Yunanca yer

Bu noktada Yunan hükümetinin Modern Yunan tarihi içinde yer isimlerini yeniden adlandırma girişimini sürdürdüğü belirtilmelidir. Bu girișimlerden birisi yer adlarının elektronik ortama tașınarak elektronik bir veri tabanı olușturulması gayesidir. Bu veri tabanında yer alan bilgilere göre -ki bu veriler 1913-1996 yılları arasındaki bilgileri içerir-, Yunan topraklarında yeniden adlandırılan toplam 4.413 yerleşim yeri adı kayıt altına alınmıştır. Kayıt altına alınan toplam isim içerisinden, 1805’i Makedonya, 827'si Peloponnese, 573’u Orta Yunanistan, 487'si Teselya, 454’ü Epirüs, 98’i Trakya, 97’i Girit, 79'u Ege Adaları, 47'si İyon Adaları olmak üzere coğrafi bölgeler yeniden adlandırılmıştır (detaylı bilgi için bkz. pandektis.ekt.gr internet adresi).

RumeliDE Dil ve Edebiyat Araştırmaları Dergisi Osmanağa Mahallesi, Mürver Ciçeği Sokak, No:14/8 Kadıköy - İSTANBUL / TÜRKIYE 34714 e-posta: editor@rumelide.com tel: +90 $5057958124,+90216773$ o 616
Address

RumeliDE Journal of Language and Literature Studies Osmanağa Mahallesi, Mürver Çiçeği Sokak, No:14/8

Kadıköy - ISTANBUL / TURKEY 34714

e-mail: editor@rumelide.com,

phone: +90 $5057958124,+90216773$ o 616 
isminin ardından parantez içinde Türkçe şeklinin verilmesine dahi izin verilmemiştir (Helsinki İzleme Raporu, 1990). İsim değişikliği Gümülcine’ye Komotini denmesi gibi şehirlerin de Yunanca isimlerle yeniden adlandırılmasına yol açmıştır. Yeniden adlandırma girişimleri bilhassa da Türklerin yoğun olarak yaşadıkları bölgelerde belirgindir. Örneğin, İskeçe’ye Xanthi, Dedeağaç'a Alexandroupoli ismi verilmiştir. Sadece şehirler değil kırsal alanlar da Yunanca birer isimle anılır duruma gelmiştir. Konuyla ilgili bir çalışma (bkz. Eren, 1988) salt Gümülcine’ye (Komotini) bağlı olup bugüne değin değiştirilen 168 köy isminin Türkçe halini ve Yunanca karşılığını vermektedir. Acaroğlu (2006), Balkanlarda Türkçe Yer Adları Kılavuzu isimli çalışmasında Yunanistan ayağında bilhassa Batı Trakya bölgesindeki yerleşim birimlerinin isimlerini alt alta yazar, listeler. "Gümülcine veya Rodop bölgesi” diyerek Gümülcine’ye bağl 188 Türk köy ismine yer verir. Bunlardan 164’ü Yunanca karşılığıyla birlikte paylaşılırken, geriye kalan köyler ise sadece Türkçe isimleriyle anılır. Konuyla ilgili yaptığı açıklamada yazar (Acaroğlu, 2006:225), Batı Trakya'daki yer adlarının, Yunanlılarca bölgenin işgali sonrasında hemen değiştirildiğini, Yunancalaştırıldığını ve belli bir süre Türkçe ile birlikte Yunanca yorumunun yan yana kullanıldığını iddia eder. Buna göre misal, Türkçe ismi Aralıkburnu olan köy "Mikitas", Kara-Musa "Mosaikon", Çeri-başı "Protaton", Habil-köy veya Hebil-köy "Hloi”; Has-köy "Hatision" veya "İtea”, Kuru-çay "Taggeon", Dağkaramusa "Trikorfon" olarak çift-dilli kullanılmıştır. 1977 yılı ile birlikte ise Türkçe yer adlarının kullanımı yasaklanır (Acaroğlu, 2006).

\section{Sonuç}

Yunan hükümetinin Batı Trakya bölgesi ile bu bölge Türklerine yönelik bitmek bilmez bir odaklanma ve müdahale etme eğiliminde olduğu görülür. Bölgeyi ve bölge Türklerini israrla takibi ve onlara dönük uğraşları, bu çalışmada da görüldüğü üzere temelde iki koldan ilerler. Bunlardan biri, bölgeden göçen Türklerle kısmen de olsa başarıyla sonuçlanır. Zira bölgedeki Türk nüfusu alabildiğine azalmış durumdadır. Bir diğeri ise Yunanlılaştırılma çabalarına rağmen Yunanlaşmayan Türk topluluğuyla başarıya ulaşamamıştır. Yunanlılaştırma veya daha teknik bir şekliyle asimilasyon, farklı örnek ve uygulamalar üzerinden yürümüş, yürümektedir. Bu uygulamalardan birkaçına değinmek gerekirse, (a) Türklere ait arazilerin "kamulaştırılması", (b) Türklerin yoğun olarak yaşadıkları bölgelerin kalkınmasını destekleyici bir müdahalede bulunmayarak, nüfus yoğunluğunun farklı bölgelere dağıtılması, (c) vatandaşlıktan iskat uygulamasıyla "azınlı" statüsüne düşürülen Türklerin bir de "vatansız" olmaya itilmeleri -ki bugünlerde bu uygulamadan uzaklaşıldığı görülür-, bunlara örnektir. Bir diğer uygulama ise (d) Yunanlılaşmaları için Türklüklerini unutturma gayretleridir. Bu noktada, Türk köylerinin kamulaştırılmasıyla ismen ve coğrafi bir uzam olarak haritadan silinmeleri, buna ilaveten yerleşim yerlerinin Yunanca isimlerle dönüştürülmeleri ve Türkçe isimlerinin telaffuz edilmelerinin yasaklanması, Yunan hükümetinin unutturmaya dönük başlıca uğraşlarıdır.

Metin içindeki örneklerden hatırlanacağı üzere, unutturma faaliyetinde mekânsal dönüşümün de etkisi bulunur. Misal Fransa, kırsal mekânda yaşayan insanları Fransızlaştırabilmek için onların kırsallıklarını unutturmaya odaklanmıştır. Dolayısıyla Yunan hükümetinin izlediği yoldan da anlaşılacağı üzere Fransa'nın bir benzerini yapmaya yönelmiş, Türkleri Yunanlılaştırabilmek için Türklüklerini unutturma girişimlerine başlamıştır. Bunun için ideal adımlardan veya uygulamalardan birisi de salt bir coğrafi bölgeyi tanımlamaktan öte kimlik, kültür ve dil gibi bir birikimi içeren yer adlarının değiştirilmesidir. Yunan hükümetinin "yer adı değişikliği”ne yönelik gayretleri, literatürde değinildiği gibi "aceleci alınmış bir karar" ve "politik bir eylem” olarak değerlendirilir. Bu noktada akla gelen ilk soru, Yunan hükümetinin Türkçe olan yer isimlerini neden aceleci şekilde değiştirdiğidir. Bir önceki cümleden ödünç alınarak soruya en kestirme şekilde "politik nedenler" cevabı verilebilir ama bu "politik" olan nedir? Asıl sorulması gereken soru budur ve bu sorudan hareketle de çalışmanın

\begin{tabular}{r|l} 
Adres & Address \\
RumeliDE Dil ve Edebiyat Arastrmalart Dergisi & RumeliDE
\end{tabular}

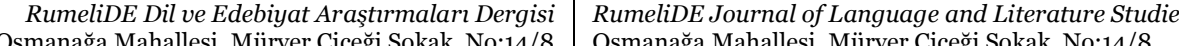
Kadıköy - İSTANBUL / TÜRKIYY 34714 Kadıköy - ISTANBUL / TURKEY 34714 e-posta: editor@rumelide.com e-mail: editor@rumelide.com, tel: +90 505 7958124, +90 2167730616 phone: +90 505 7958124, +90 2167730616 
Assimilation, forced forgetting (effacing cultural memory) and name change (special for toponymy) in Western Thrace / S. Adiloğlu (pp. 510-526)

vücut bulduğu belirtilmelidir. Metin içerisinde “yer adlarının” ne denli önemli olduğu, farklı açıklama ve iddialardan hareketle dillendirilir. Örneğin, kimi düşünüre göre yer adları, kültürel birer mirastır ve muhafaza edilmeleri gerekir, bazıları, yer isimlerinin bölgenin kontrolüne dair bilgi verdiğini, çift isimli bir tabelanın çift kimlikli bir bölgeyi ima ettiğini ve kontrolün de bir anlamda bölüşüldüğünü iddia eder. En nihayetinde ise geçmişi içinde barındıran özelliğiyle yer isimlerinin çok işlevli olduğu, geçmişin kontrol edilebilmesinin geleceği de kontrol edebilmesine imkân yarattığı fikri vardır ki, Yunan hükümetinin bölgedeki Türkleri asimile etmeye dönük uğraşları göz önünde bulundurulduğunda yer isimlerindeki değişikliğe gitme davranışı anlamlı hale gelir. Bu hükümet sadece buradaki gibi geçmiş ve geleceği kontrol etmekle yetinmeyip aynı zamanda "yapay" bir Yunan coğrafyası kurmanın derdindedir. Bu yeni kurguda Yunanlılara ve Yunanlılaştırılanlara yer vardır, ötekilerine ise yer yoktur. Yunanlılaştırabilmede yönetimin başvurduğu uygulama ise dikkat çekmeyen ve sessizce gerçekleşebilen yer ismi değişiklikleridir. Bugüne değin kaç yerleşim biriminin ismen değiştiği bilinmemekte, araştırılması dahi çok olası görüşmemektedir. Ancak konu ve bölgeyle ilgili olarak bilinen bir gerçek vardır ki o da, yaşanan isim değişikliklerinin en azından şu an için bölge Türklerinin dil ve kimlik aidiyetlerinde bir dönüşüm yaratmadığıdır. Bununla birlikte Yunan hükümetinin unutturma gayretine hizmet etmeyen ancak bugün Yunancaya çevrilmiş isimleriyle Türk köyleri, bağlamından kopuk şekilde ve yazar Kulavkova’nın iddiasına benzer şekilde, ruhtan üsluptan, karakterden, kader ve tarihten yoksun birer isme sahiptir.

\section{Kaynakça}

Acaroğlu, M. T. (2006). Balkanlar'da Türkçe Yer Adları Kılavuzu. İstanbul: IQ Sanat.

Ahmet, S. (1995). Batı Trakya'da Yaşayan Türk Toplumunun Şikâyetleri ve İstekleri. Milletlerarası Hukuk ve Milletlerarası Özel Hukuk Bülteni, 15(1-2), 1-10.

Ahmet, S. (2011). Batı Trakya'da Yaşayan Türk Toplumunun Şikâyetleri ve İstekleri. Milletlerarası Hukuk Ve Milletlerarası Özel Hukuk Bülteni, 15 (1-2), 1-10.

Alioğlu-Çakmak, G. (2018). Bir “Avrupa” Azınlı̆̆ı olarak Batı Trakya Türkleri. İstanbul Gelişim Üniversitesi Sosyal Bilimler Dergisi, 5 (2), 149-168.

Alp, İ. (1995). Batı Trakya Türkleri. Atatürk Araşttrma Merkezi Dergisi, XI(33), 613-652.

Altınsöz, M. (1988). Türk Varlığı. Batı Trakya’nın Sesi Dergisi, 2.

Assmann, J. (1997). Kültürel Bellek Eski Yüksek Kültürlerde Yazı, Hattrlama ve Politik Kimlik. (Çev. Tekin, A.). İstanbul: Ayrıntı.

Ayhan, H. (2014). Batı Trakya Türk Azınlığının Hukuki ve Siyasi Sorunlarının Asimilasyon Politikası Çerçevesinde Tahlili. Dumlupınar Üniversitesi Sosyal Bilimler Dergisi, 42, 173-188.

Bahcheli, T. (2007) The Muslim-Turkish Community in Greece: Problems and Prospects, Institute of Muslim Minority Affairs. Journal, 8(1), 109-120.

Bakirtzis, M. I. \& Constantinides, Th. N. (2014). Adminsitrative Division and Toponymic Tradition in the Xanthi A-and Ghenisea Region, from the Beginning of Ottoman Rule until 1928. İç. (Ed.) Balta, E. Salakidis, G. Stavrides, Th. Studies on the Ottoman Empire and Turkey. İstanbul: The ISIS.

Balkaç, Z. (2015). Batı Trakya Türkleri. Yeni Türkiye, 4(69).

Baltalı, İ. (2009). Demolished Ottoman Historic Monuments and Expropriated Lands in Western Thrace. Iç. Osce Supplementary Human Dimension Meeting Freedom of Religion or Belief. Komitini: Western Thrace Minority University Graduates Association.

Cin, T. (2009). Batı Trakya Türklerinin Hukuki Statüsü Sorunları ve Avrupa Birliği. Dokuz Eylül Üniversitesi Sosyal Bilimler Enstitüsü Dergisi, 11(1), 147-179.

Connerton, P. (2014). Modernite nasıl unutturur. (Çev. Kelebekoğlu, K.). İstanbul: Sel.

\begin{tabular}{r|l} 
Adres & Address \\
RumeliDE Dil ve Edebiyat Araşțrmaları Dergisi & RumeliDE Journal of Language and Literature Studies \\
Osmanağa Mahallesi, Mürver Çiçeği Sokak, No:14/8 & Osmanağa Mahallesi, Mürver Çiçeği Sokak, No:14/8 \\
Kadıköy - İSTANBUL / TÜRKİY 34714 & Kadı̈öy - ISTANBUL / TURKEY 34714 \\
e-posta: editor@rumelide.com & e-mail: editor@rumelide.com, \\
tel: +90 505 7958124, +90 216 773 o 616 & phone: +90 505 7958124, +90 216 773 o 616
\end{tabular}


De Souza, C. P. Beatriz. (2015). The Cultural Heritage of Geographical Names in the City of Petrópolis, Rio de Janeiro - Brazil. UNGEGN Information Bulletin, 48. 1-2.

Değirmendereli, A. (1993). Batı Trakya ve Doğu Anadolu Köy Adlarının Karşılaştırılması. Batı Trakya'nin Sesi. Sayl 57.

Eren, H. (1988). Batı Trakya'da Türk Yerleşim Bölgeleri Batı Trakya'da Rodop Vilayeti’ne Bağlı Yer adları. Batı Trakya’nın Sesi Dergisi. Sayı 6.

Featherstone, K. vd. (2011). The Muslim Community of Western Thrace in Context. İç. The Last Ottomans The Muslim Minority of Greece, 1940-1949. New York: Palgrave Macmillan.

Grounds, A. R. (2001). Tallahassee, Osceola, and the Hermeneutics of American Place-Names. Journal of the American Academy of Religion, 69(2), 287-322.

Gülmez, N. \& Akdeniz, M. (2015). Kıbrıs Barış Harekâtı’nın Batı Trakya Türkleri Üzerindeki Etkileri. Yeni Türkiye, 4(69).

Güvenç, S. (2014). Mübadele Öncesi ve Sonrası Eski ve Yeni Adları ile Kuzey Yunanistan Yer Adları Atlası. (2. Baskı). İstanbul: Lozan Mübadilleri Vakfı.

Hacısalihoğlu, M. \& Özcan, G. (2013). Balkanlarda Yer İsimlerinin değiştirilme siyaseti: Avusturya, Yunanistan, Bulgaristan ve Türkiye örnekleri. İç. Türk Tarihinde Balkanlar. Cilt II. (Ed. İskefiyeli, Z., Çelik, M. B. \& Yazıcı, S.). Sakarya: Sakarya Üniversitesi Balkan Araştırmaları Uygulama ve Araştırma Merkezi.

Hatipoğlu, M. M. (1997). Yakın Tarihte Türkiye ve Yunanistan 1923-1954. Ankara: Siyasal.

Hüseyinoğlu, A. (2015). Balkanlarda Azınlıklar ve Siyasal Katılım Hakkı: Batı Trakya (Yunanistan) Örneği. Yeni Türkiye, 69. 4777-4786.

Jansen, Y. (2013). Secularism, Assimilation and the Crisis of Multiculturalism: French Modernist Legacies. Amsterdam: Amsterdam University Press

Jordan, P. (2012). Place names as ingredients of space-related identity. (Ed.) B. Helleland, C.-E. Ore \& S. Wikstrøm. İç. Names and Identities, Oslo Studies in Language. 4(2), 117-131.

Kadmon, N. (2004). Toponymy and Geopolitics: The Political Use -and Misuse- of Geographical Names. The Cartographic Journal, 41(2). 85-87.

Kamozawa, I. (1982). Ethnic Minority in Regionalization: Case of Turks in Western Thrace. Population Mobility in The Mediterranean World: Studies in the Historical and Contemporary Aspects, 125-137.

Kandler, H. (2007). Greek Thrace: A Region Populated by Christians and Muslims in the European Mediterranean. Europa Regional, 15.2007(2), 75-86.

Kayam, C. (1993). Lozan Barış Antlaşmasına Göre Türk-Yunan Nüfus Mübadelesi ve Konunun TBMM'de Görüşülmesi. Atatürk Araşttrma Merkezi Dergisi, 9(27), 586-587.

Konortas, P. (2013). Nationalist infiltrations in Ottoman Thrace (ca.1870-1912): The Case of The Kaza of Gumuljina. . (Ed.) Benjamin, C. F. vd. İç. State-Nationalisms in the Ottoman Empire, Greece and Turkey Orthodox and Muslims, 1830-1945. Abingdon: Routledge.

Krispis, A. (2016). The Local Government in Greece a descriptive approach. Athens: Hellenic Association of Political Scientists.

Kulavkova, K. (2012). Enforced linguistic conversion: translation of the Macedonian toponyms in the 20th century. Slavia Meridionalis, (12), 206-221.

Makas, Z. (1993). Ermenistan'da Adları Değiştirilen Bazı Türk Yerleşim Yerleri Üzerine. Ondokuz Mayıs Üniversitesi Ĕ̆itim Fakültesi Dergisi, 7(1), 135-146.

Neethling, B. (2016). Street Names: A Changing Urban Landscape. İç. The Oxford Handbook of Names and Naming. Ed. Hough, C. Oxford: Oxford University Press.

Oran, B. (1986). Türk-Yunan İlişkilerinde Batı Trakya Sorunu. Ankara: Mülkiyeliler Birliği Vakfı.

\begin{tabular}{|c|c|}
\hline & \\
\hline aları $D$ & d Literatur \\
\hline $\mathrm{Mal}$ & Mahallesi, Mürver Çiçeği Sokak, No:14/8 \\
\hline Kadıköy & STANBUL / TURKEY 34714 \\
\hline $\begin{array}{r}\text { e-posta: edito } \\
\text { tel: }+905057958124,+\end{array}$ & $\begin{array}{l}\text { editor@rumelide.com, } \\
\text { +90 505 7958124, +90 } 216773 \text { o } 616\end{array}$ \\
\hline
\end{tabular}


Assimilation, forced forgetting (effacing cultural memory) and name change (special for toponymy) in Western Thrace / S. Adiloğlu (pp. 510-526)

Öksüz, H. (2015). Batı Trakya'dan Türkiye’ye Göç (1923-1950). Yeni Türkiye, 4. Cilt, Sayı. 69.

Pinchevski, A. \& Torgovnik, E. (2002). Signifying Passages: The Signs of Change in Israeli Street Names. Media, Culture \& Society. 24(3). 365-388.

Sarı, M. (2015). Atatürk Dönemi İç Anadolu Bölgesi’nde İmar - İskân Faaliyetleri (1923-1938). Ankara: Atatürk Kültür, Dil Ve Tarih Yüksek Kurulu Atatürk Araştırma Merkezi Yayınları.

Serdar, A. (2014). Tarihsel Süreç İçerisinde Batı Trakya Türklerinin Ekonomik ve Demografik Gelişimi. Balkan Araştırma Enstitüsü Dergisi, Cilt/Volume 3, Say1/Number 2, 97-126.

Verhas, E. (2019). Batı Trakya'daki Türk Azınlı: Uzun Yillardır Süren Hak ve Tanınma Mücadelesi. Budapeşte: Minority Rights Group Europe Yayını.

\section{Internet kaynakları}

“Demografi” Avrupa Batı Trakya Türk Federasyonu. https://www.abttf.org/batitrakya.php?id $=53$

"Destroying ethnic identity the Turks of Greece". (1990). A Helsinki Watch Report (Helsinki İzleme Raporu 1996). Washington: Human Rights Watch. https://www.hrw.org/reports/pdfs/g/greece/greece9o8.pdf

"Kronoloji”. Batı Trakya Online Haber Ajansı. Erişim: https://www.batitrakya.org/batitrakya/bati-trakya-tarihi/kronoloji.html

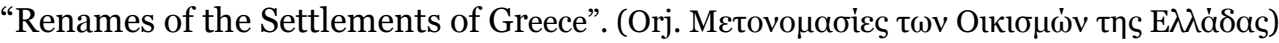
http://pandektis.ekt.gr/dspace/handle/10442/4968

"Yunanistan 544 Batı Trakya Türkü'nü Vatandaşlıktan Çıkardı" (1991). Batı Trakyanın Sesi Dergisi, Sayı 3o. 4-15.

https://docs.google.com/viewerng/viewer?url=http://www.batitrakya.org/dosya/ bati-trakyanin-sesi-dergisi/bati-trakyanin-sesi-dergisi-sayi-30-1991.pdf\&hl=tr

"Yunanistan, 544 Batı Trakya Türkü’nü vatandaşlıktan çıkardı" (1991). Batı Trakya’nın Sesi Dergisi, sayl 30. https://www.batitrakya.org/e-bati-trakya/bati-trakyanin-sesi-dergisi/batitrakyanin-sesi-dergisi-sayi-3o-1991.html

RumeliDE Dil ve Edebiyat Araştırmaları Dergisi Osmanağa Mahallesi, Mürver Ciçeği Sokak, No:14/8 Kadıköy - İSTANBUL / TÜRKIYE 34714 e-posta: editor@rumelide.com tel: +90 $5057958124,+902167730616$
Address

RumeliDE Journal of Language and Literature Studies

Osmanağa Mahallesi, Mürver Çiçeği Sokak, No:14/8

Kadıköy - ISTANBUL / TURKEY 34714

e-mail: editor@rumelide.com,

phone: +90 505 7958124, +90 2167730616 